\title{
Understanding rules as habits. Developing a pragmatist anthropological approach
}

The sections of the Philosophical investigations devoted to the problem of following a rule are among the most discussed in the secondary literature on Wittgenstein. ${ }^{1}$ The problem of how we can apply a certain rule, that is how we can transform a rule into a principle for acting in a certain way, seems to present an inescapable impediment. If we think that the link between a certain rule and a specific behaviour can be represented by a particular interpretation of the rule itself - a Deutung in German - we will have to face the paradox that every action could be connected to the rule itself by means of a certain interpretation. Hence, Wittgenstein provisionally concludes that an interpretation by itself cannot determine the meaning of a rule and remains suspended in the air together with what it is interpreting.

How, if at all, can we escape the sceptical paradox, as this was notoriously labelled by Saul Kripke?

In a short but perspicuous essay dating back to 2010, Jean-Pierre Cometti argued that here Wittgenstein was discussing the traditional way of understanding rules, that is as formal norms, as certain propositional contents existing in our minds or somewhere else and a priori in reference to their possible actualizations. ${ }^{2}$ In other terms, rules are here supposed to have the capacity to rationally direct our conduct - as if there were an a priori normative level laying behind and before our ordinary practices, whereby our acts find a meaning which they would otherwise be devoid of by being interpreted as the application of a certain rule.

The point is that - to paraphrase a famous formula - there is a way to understand a rule that is not an interpretation. From a pragmatist point of view, Wittgenstein seems to be pushing his reader to make a jump from the

* Università Ca' Foscari, Venezia, Dipartimento di Filosofia e Beni culturali, robdre@unive.it.

1 Among the most outstanding protagonists of the debate on Wittgenstein's notion of following a rule, I will only mention Winch (1990; $2^{\text {nd }}$ ed.); Kripke (1982); Diamond (1983) and McDowell (1984).

${ }^{2}$ Cometti (2008) characterizes this conception of rules as the «regulist» one, in accordance with Brandom (1994) and his differentiation between regulism and regularism. See also Perissinotto (1997, pp.105-109).

Paradigmi. Rivista di critica filosofica, n. 3-2016 
alleged dichotomy between the two levels - the normative one and that of our empirical acts - by recognizing the priority of shared, already more or less regular and meaningful practices.

We could say that here the issue at stake is the idea of what many years later Pierre Bourdieu characterized as the logic of practice, which can be objectified and translated into the schemes of our explicit rationality. But the reverse cannot be argued from an ethnographic point of view - I mean the idea that the logic of practice is dependent upon and derived from normativity (Bourdieu, 1972; 1980). However, as it is well known, Wittgenstein probably would have not accepted such a structured philosophical thesis, because he understood his philosophical work as rather consisting in the rejection of theoretical encrustations - in this case represented by the idea of following a rule as something always in need of an interpretation with the aim of letting our variety of practices be looked at.

What has to be looked at is not propositional contents or the mental representations of a certain rule, but uses (Gebräuche), techniques and habits (Gepflogenheiten). Moreover, Wittgenstein explicitly states that uses, practices, techniques and habits - together with institutions - are not only the product of our minds, but also part of a shared form of living. Hence his final comment that a rule cannot be followed privately.

My suggestion is that what Wittgenstein means by rule here could better be understood in terms of habits, as these have been theorized by the classical pragmatists - and by John Dewey in particular. Some support for my hypothesis can be found in the set of terms frequently used by Wittgenstein in his original German version of the Philosophical investigations - «ständige Gebräuche», «Technik», «Praxis», «Institutionen» and «Gepflogenheiten», that is habits. Furthermore, Wittgenstein's well known anthropological interests, coupled with his declarations about adopting an ethnographic perspective on language and on forms of living, seems favourable to my proposal. ${ }^{3}$

However, it is for a different set of reasons that I suggest to translate Wittgenstein's rules into Dewey's habits. First of all, the point is that in speaking of habits, the intellectualistic interpretation of the following of rules is simply excluded: in arguing that human games - both linguistic games and all other ones - are ruled by habits, it would be rather strange to envision a habit as a pre-existing rule that needs to be processed inside the mind of the agent in order to be applied to a given practice. From this point of view, it would seem bizarre to consider habits as constituting a separate a

${ }^{3}$ On Wittgenstein and anthropology, see Borutti (1985), Andronico (1998), and Rofena (2011). 
priori realm, prior to any potential actualization they could realize. The domain of habits is that of practice itself and, for sure, of shared practice be it peacefully shared or challenged.

This last aspect brings us to the second motivation supporting my suggestion that rules belonging to a certain form of living could be better understood as habits. Of course there are idiosyncratic, highly subjective habits, but ordinarily habits are acquired by an individual by means of his exchanges with other persons - from the more bodily behaviours to the more refined and intellectualized ones. It would be absurd to conceive of habits as configuring themselves in a kind of pneumatic vacuum. Habits are primarily social and cannot be followed privately. Every woman or man develops her/his own personal style in following a habit, but this does not mean that her/his habits can be ascribed to her/him as her/his «exclusive ownership» (Dewey, 1988a, p. 15). On the contrary, this shows just how deep habits go in shaping people's self-identity.

Moreover, from a Deweyan point of view, this interpretive key permits us to reinforce the pragmatist idea that habits play a crucial role in configuring our moral, political and economic behaviours: as they ordinarily have no need to be interpreted - no need to find a Deutung to be translated into an empirical act - they seem very deeply rooted in our practices, so that they are unconsciously felt as being almost natural. This means that they can be extremely projective, self-moving and powerful, but also dangerous because of their quasi-automatism and rigidity. ${ }^{4}$

Of course there are also some difficulties that could arise from understanding rules as habits. A general preliminary remark is that we are widening the field. Habits are not only restricted to linguistic rules but extend to every human practice - from standing upright and walking to making forecasts about the weather, from playing games and musical instruments to imagining and thinking. In Wittgenstein's terms we could state that habits constitute our forms of living.

But the first problem regards Wittgenstein's interpretations. Understanding Wittgenstein's rules as Dewey's habits means pushing Wittgenstein himself to complete his leap - I mean the leap from the dichotomy between the alleged a priori norms and their alleged empirical actualizations to our

${ }^{4}$ Regarding bad habits, Dewey (1988a, p. 21) states: «These traits of bad habits are precisely the things which are more instructive about all habits and ourselves. They teach us that all habits are affections, that all have projective power, and that a predisposition formed by a number of specific acts is an immensely more intimate and fundamental part of ourselves than are vague, general, conscious choices. All habits are demands for certain kinds of activity; and they constitute the self». 
already meaningful ordinary practices - by making the anthropological consequences of such a leap explicit.

Of course many scholars of Wittgenstein could argue that the Austrian philosopher would have refused to consider his philosophical work as involving positive formulations about our alleged human nature. While the problem might be of interest for the followers of Wittgenstein, it is more marginal for the general issue we are investigating in this paper, that is whether we can understand rules as habits and what the consequences of this might be.

There is one further compelling issue to be addressed in relation to my hypothesis: if we understand rules as habits, does this mean that we lose all chances to reach a normative level and that we are therefore compelled to espouse a radical form of old-fashioned relativism? While I will try to answer this question in the last section of the paper, I can already state that from a Deweyan point of view we should run the risk even if we have no guarantee when it comes to the question of normativity.

The central point of reference for the present inquiry is represented by Dewey's Human nature and conduct, even though I will make a certain number of references to the other classical pragmatists, on whose shoulders Dewey partially stood when developing his own articulated conception of habits - from James's psychology, to various essays by Mead from the first decade of the $20^{\text {th }}$ century, to Peirce's connections between doubts, beliefs and habits. Dewey's insights are very rich, but I will focus on those aspects that, in my opinion, are more significant in relation to Wittgenstein's investigations on what it is like to follow a rule.

\section{Radical externalism}

Before articulating the anthropological assumptions characterizing the pragmatist approach to habits and before facing the problem of what space there is for norms if we speak about rules in terms of habits, we have to say something about Dewey's general stance on habits, which prevents us from slipping into an intellectualistic or formalistic reading of the following of rules.

From the very beginning of his book Dewey clearly adopts what we could describe as an externalist approach. When explaining the meaning of his book subtitle - An introduction to social psychology - he argues:

Perhaps the sub-title requires a word of explanation. The book does not purport to be a treatment of social psychology. But it seriously sets forth a belief that an 
understanding of habit and of different types of habit is the key to social psychology, while the operation of impulse and intelligence gives the key to individualized mental activity. But they are secondary to habit so that mind can be understood in the concrete only as a system of beliefs, desires and purposes which are formed in the interaction of biological aptitudes with social environment (Dewey, 1988a, p. 3).

It is very clear that - whereas rules seem to have a more ambiguous status - habits are first of all to be found in the social contexts inhabited by humans, rather than being something installed in their minds, whether in the form of representational contents or as universal norms and transcendental principles we could grasp. On the contrary even minds have to be understood as being deeply influenced by social habits, as emerging qualities of peculiarly human modes of interaction with the environment.

Even more radically, 20 years before, in an essay devoted to The interpretation of savage mind (Dewey, 1976). Dewey contended that our minds have to be understood as «organ[s] of service for the control of the environment in relation to the ends of the life process», that is as functions of the structural interactions of the human organism with its environment. Particularly in order to understand the typical mental form of a community, we have to focus on the occupations and main social practices carried out by that group of people to survive - such as hunting and fishing or practicing agriculture and rearing. These external practices are the ones influencing the formation and use of habits and the consequent development of a certain kind of mental type or psychosis - that is, of a certain prevalent style of interaction with the environmental context to which a given form of human life belongs. In Wittgenstein's terms we could say that rules are always rooted in a form of living and that linguistic rules are involved in a linguistic game, while our sense of being a self is shaped by both of these factors.

In order to suggest a synthetic definition of Dewey's conception of habits, it could be said that they are functions of the structural interactions between a living organism which has got an overwhelming number of noninstinctually directed energies, and the natural and naturally social environment this organism belongs to. They are more or less stable, more or less dynamic canalizations of these energies, which are basically acquired from the social group the human organism belongs to. In other terms, habits are more or less regular ways of responding to the actions of the environment, both in its natural and in its social features.

The physiological similitude suggested by Dewey plays a refreshing role here against the idea that rules and habits lie in our mind or belong to a detached realm of norms, separate from the field of empirical (psychological, causal) causes of our actions and their consequences. 
If we look at physiological functions, we can see that breathing and digesting are both based on oxygen and food as well as on the lungs and stomach. If we now understand the habit of walking as being analogous to breathing, we can see that it is constituted both by our sensory and motor organs as well as by the conditions of the surface we are moving on; or if we consider the habit of - say - playing the guitar, we can see that it is based both on the touch of the musician's fingers - on his sense of rhythm - and on the acoustic qualities of his musical instrument, but also on the listening dispositions of the people who may be present at the performance.

This means that if habits have a special reference to a certain agent - to an individual guitar player, for example - we cannot «convert this special reference into a belief of exclusive ownership» (Dewey, 1988a, p. 16).

\section{A naturalistic approach to habits}

The most distinctive feature characterizing Dewey's conception of habits, in my opinion, is the strong convergence of biological, physiological and, so to speak, natural aspects of the homo sapiens with his structurally social nature. It is in this core of ideas that we have to search for an understanding of the almost astonishing statement - Dewey openly speaks here of a paradox - that, even if habits are acquired, they are primary, while individual impulses, despite being native, are secondary and dependent (p. 65).

We will return to this point later on, because an important window in this regard has to be opened on James.

As it is well known, a strong naturalistic stance was already present in William James's approach to human habits in his Principles of psychology, which deeply influenced Dewey's conception - maybe precisely because of the fact that James was able to avoid a reductionistic or materialistic approach. ${ }^{5}$

On the contrary, as David E. Leary argues, «Habit [...] was the key to James's solution of the dilemma that he faced as he weighed the intellectual attractiveness of an entirely materialistic and causal explanation of human

${ }^{5}$ In a later essay, entitled "The vanishing subject in the psychology of James", Dewey (1988b) emphasizes the double tendency characterizing James's Principles of psychology. While explicitly adopting a dualistic epistemology, based on the distinction of the psychic from the physical, James allowed the subject to be dissolved into an organism, whose behaviour was not seen to spring from within the organism, but was rather conceived as a function of the environment. According to this Deweyan reading of James, the treatment of habits is particularly meaningful with respect to this kind of continuistic and functionalistic biological approach. 
existence $[\ldots]$ against the equally compellingly moral imperative to believe that he could and should live a responsible and meaningful life». ${ }^{6}$

This is a very important aspect to be noted, because I think that we cannot understand the pragmatist approach to habits if we focus only on the social and cultural characterization of these categories, while marginalizing the natural components. To state this thesis differently, even if both James's theory of habits and Dewey's greatly emphasize social factors, they are not equivalent to, say, Bourdieu's conception of habitus. Their confident naturalism - but this was equally true for George Mead, of course - constituted a barrier against the possibility of falling into too radical forms of social constructivism as well as against the possibility of interpreting the role of habits in relation to social conduct as a kind of almost monistic determinism. $^{7}$

For the classical pragmatists - particularly for James, Dewey and Mead - the philosophical treatment of habits must start from our being living creatures, that is our being organisms who have to relate to an Umwelt to breathe, nourish themselves, reproduce, and even to understand, speak and find meanings. This biological obviousness (Dewey, 1989, pp. 19-20) sounds very refreshing if compared to the entrenched modern philosophical assumption that a subject is as an autonomous entity, independently configured apart from the reality it can engage with. For all classical pragmatists, habits cover an extremely wide portion of our lives, so that even our personal identities can be considered the outgrowth of the ways in which we react to the environment and ceaselessly contribute to reconfiguring it from the inside.

The key concept to understand James' interpretation of habits is that of plasticity, which was notoriously influenced by Darwin. However, plasticity is not conceived as the exclusive property of the nervous system, but as something characterizing all forms of matter, even inanimate matter - even though, of course, differences of degree are extremely meaningful.

The point is that plasticity is understood in structural, relational terms by

${ }^{6}$ Leary (2013, p. 178). See also Calcaterra (2016), who strongly emphazises James' continuistic stance across the fields of philosophy, psychology and biology and its connection to his deeply undeterministic attitude in ethical and political matters. There is not the space here for a comparative discussion of Dewey's conception of habits and Bourdieu's notion of habitus, but I have explored the topic in a previous essay of mine (Dreon, 2010). For a different approach, more focused on the points of contact between the two authors, see Colapietro (2004).

${ }^{7}$ There is not the space here for a comparative discussion of Dewey's conception of habits and Bourdieu's notion of habitus, but I have explored the topic in a previous essay of mine (Dreon, 2010). For a different approach, more focused on the points of contact between the two authors, see Colapietro (2004). 
James: «in the wide sense of the word [it] means the possession of a structure weak enough to yield to an influence, but strong enough not to yield all in one» (James, 1981, chapter IV). In other words, plasticity is clearly a function of the interdependence of a certain matter from the actions that can be carried out upon it within a certain context. Hence, «the phenomenon of habit in living beings is due to the plasticity of the organic materials of which their bodies are composed». Because of the distinctively high degree of plasticity of our nervous system, repeated actions and behaviours can draw neural paths, which are ways of responding to environmental influences with the tendency to stabilize themselves. This means that James considers the human nervous system not a fixed entity, completely equipped with all properties, but rather an entity which dynamically configures itself in relation to what is happening around it.

Against the current trends towards forms of physical reductionism, and particularly the dogmatic idea of the causal closure of the physical realm, ${ }^{8}$ James considered our brain a function of the environment and as having a history. ${ }^{9}$ The brain seems to be dynamically shaped by those actions that are selected, reinforced and preferred to other behaviours because of their capacity to simplify an otherwise too complicated and indeterminate variety of responses we can give to environmental events - given that we have lost the majority of merely instinctual reactions in comparison to other animals. Furthermore, habits ensure more space and time for selective attention, by allowing the majority of our behaviours to be implemented without conscious deliberations. As pointed out by David Leary, a biological understanding of habits did not push James to become a radical materialist, but on the contrary allowed him to leave some space for human choices, especially moral ones. ${ }^{10}$

\section{Social anthropology as the counterpart of natural anthropology}

John Dewey also devotes much attention to human plasticity, but, as is often the case among the classical pragmatists, the same topic is considered from different perspectives, integrating or redirecting the whole discourse. Because his approach starts from a crucial understanding of life as an interaction between an organism and its natural environment, the point for Dewey is that in the human case the exchanges are particularly dynamic

${ }^{8}$ On the differences between the current naturalization trend in philosophy and the kind of naturalism characterizing the classical pragmatists, see Margolis (2002, pp. 6-7).

9 For an interesting convergence with current hypotheses, see Mithen and Parsons (2008).

${ }^{10}$ Leary (2013, section 5, "Conclusion"). 
and basically open. This indeterminacy is not only due to the lack of fixed, instinctual behavioural answers characterizing the human being, but also to the extremely varied range of environmental contexts characterizing human forms of living from every point view - from the geographical to the cultural, historical and social. Because «the environment in which the act takes place is never twice alike» (Dewey, 1989, pp.19-20), it is necessary for human beings to behave in a flexible enough way to adapt to different situations, as well as channel their forces into relatively regular habits.

However, Dewey's major point is connected to the issue of social psychology understood as a complementary part of a naturalistic approach to psychology - this claim was strongly upheld both by Dewey and by Mead, one of whose famous essays, published in 1909, bears the eloquent title "Social psychology as counterpart of physiological psychology" (Mead, 2011a). It could be argued that for both authors a crucial element is constituted by the lack of references to a psychic or interior dimension of psychology - considered as the point of departure. The starting point for both of them was human social nature and behaviours, rather than the psychic contents of the mind or of consciousness.

In Human nature and conduct Dewey deeply emphasized the main social characterization of human natural environments. For humans the most important events occurring in their natural environment are constituted by the behaviour of other people - be they friends or enemies, intimates or aliens. But this is not based, according to Dewey, on the metaphysical belief of an alleged priority of the social over the individual. This happens because of the circumstances surrounding the birth of every human being. Dewey frequently points out that human babies are particularly vulnerable creatures at birth: because of their immatureness at birth, they are necessarily dependent upon the social group they belong to in order to survive at every level - from finding nourishment and protection against aggressive agents to developing self-confidence and rich, meaningful relationships. Our being dependent, helpless beings at birth and for the rest of our life requires the attention of others and these circumstances create the space for habits, previously channelled behaviours, shared customs, and traditional pattern of action. This is why the human environment is naturally social and this is why social habits and customs, while acquired by individual human beings, are already there before an individual can take part in a shared practice and find a place within it. This is why, although impulses are innate, they always have to do with the previously established habits to which every child is exposed from birth (Dewey, 1988a, pp. 43-45, 60 and 65-66). Shared behavioural patterns already represent a sort of almost obvious or silent background from which individual instances can emerge and 
find a distinctive shape. This is the solution of the apparent paradox of acquired habits being primary and native impulses secondary: the crucial feature is that the human ecological dimension is a naturally social one and a certain shared context (either a welcoming one or a hostile one) is already there before we can respond, by saying for the first time "I".

On this subject, there is a crucial convergence between Dewey and George Herbert Mead, which reinforces the hypothesis that the two of them were working at least partially together on this issue. In an unpublished essay, whose date remains unknown, The relation of the embryological development to education, Mead quotes John Fiske, who

[...] has worked out in some detail the value of the long dependence of the child form upon the parent forms in the evolution of society. He has shown that no animal which had so long a period of dependence could possibly have survived, unless he grew up within a community in which all the essentials of our social relations were at least implicitly contained (Mead, 2011b, p. 73).

Mead, in particular, derives from Fiske's idea of the primary social importance of infancy the hypothesis that habits can develop precisely because the period of high dependence of the child is very long. If the baby adapted very quickly, almost instinctively, to his environment, he could not develop those precious habits which are so favourable to the emergence of higher forms of intelligence. Hence it is clear that Mead not only adopted a continuistic stance with reference to habitual behaviours and their connection to intelligence, but also conceived of reason as being largely dependent upon habitual practices. This does not mean that for both Dewey and Mead there is no more space for reflexive actions, conscious deliberations and intellectualized norms, but that they regard these as emerging from more habitual bonds within a shared form of living. ${ }^{11}$

Furthermore, Dewey maintains that this condition of dependence upon a social group is not exclusive to our infancy, but that it shapes the rest of human life - our basically outer-oriented sexuality being an exemplary case mentioned by the American philosopher, who was probably implicitly reconsidering the weight of sexual selection in Darwin's theory.

Finally, there is one last element which explains why according to Dewey, James and Mead habits play a crucial role in our interactions with the world around us.

${ }^{11}$ I think that Shannon Sullivan's current attempt to face ethical and political issues such as racism and feminism from a biological perspective could be reinforced by referring to this conception of basic human dependency - whereas her claim is fundamentally based on human embodiedness. See Sullivan (2013). 
In addition to human plasticity - in all of its different configurations and to basic human social dependence, we must recall the pragmatists' decisive acknowledgement of the fact that the one who feels, acts, thinks, speaks and makes choices is a living body, an organism. Only a disembodied consciousness or a divine being could give origin to a new action completely ex nihilo. On the contrary, a human being must always channel preexisting energies in a new direction, always starting from a background of already acquired paths. The philosophical tendency to sever the means from the ends - the mere empirical tools from the alleged ultimate valuable principles - has led us astray:

In the case of no other engine does one suppose that a defective machine will turn out good goods simply because it is invited to. Everywhere else we recognize that the design and structure of the agency employed tell directly upon the work done. Given a bad habit and the «will» or mental direction to get a good result, and the actual happening is reverse or looking-glass manifestation of the usual fault $-\mathrm{a}$ compensatory twist in the opposite direction. Refusal to recognize this fact only leads to a separation of mind from body, and supposing the mental or «psychical» mechanisms are different in kind from those bodily operations and independent of them. ${ }^{12}$

\section{The place for reflexive habits and norms}

What has just been described is only one side of the issue of habits in the classical pragmatist tradition.

As it is well known (Kestenbaum, 1992), the pragmatists and particularly Dewey were very critical of the epistemologically oriented idea of human experience according to which this should be mainly or eminently considered equal to knowledge; and they were equally critical of the intellectualistic assumption that theory should precede practice - more precisely, that an explicit set of transcendental norms and values should be assumed as ruling our conduct and life practices a priori. As neatly summed up by Victor Kestenbaum, «we are habitual beings and not simply epistemological subjects seeking to reach agreement about the objects of the world» (Kestenbaum, 1992, p. 34).

Obviously, this does not mean that in this philosophical tradition there is no more space for reflection, for more intelligent habits and conscious deliberations. Habits can and must be changed, whenever they do not work, every time an old habit is in crisis and cannot help us face the new condi-

${ }^{12}$ See Dewey (1988a), pp. 43-45, p. 60 and pp. 65-66. 
tions of the context we are confronted with. It is precisely when the problem of what to do explicitly arises in our consciousness that a previous habit can and must be checked, rejected or modified through the intervention of both individual native impulses and reflexive analysis. We have no need to imagine an alleged separate psychic or mental realm for new habits and explicit rules to be set. On the contrary, our exchanges with a certain environmental context become intelligent or mental whenever a previous habit appears problematic and we need to revise it and analytically consider the new situation.

Moreover, in those cases where a certain habit has to be changed into a different rule of action, a whole set of background habits are nevertheless still at work - particularly those habits giving our thinking selective emphasis, discriminative power, analytical force, and so on. Hence, habits can always be revised in part, every time there is a reason to do so - either because the context has changed or because we are no longer the same persons or no longer have the same needs.

This solution was, in my opinion, clearly influenced by Peirce's antiCartesianism and by his notorious treatment of doubt. We are not always required to doubt. The condition of doubt is artificial and misleading if it is generally applied to every case of rule-following (Bernstein, 2010, chapter I). We doubt only when something goes wrong in our ordinary, largely habitual conduct. When something does not work, the irritation of doubt arises and it can only cease when a new belief takes shape, that is a new «rule of action» or «for short, $a$ habit» - a new one, better suited to the altered conditions of the context (MacMullan, 2013, p. 232). But if we considered only this part of Peirce's famous essay on "The fixation of belief", the picture would not be complete. The point is that also for drawing one inference rather that another, some «habit of mind» must still be at work. There is neither a direct line from theory to practice, nor a direct line from practice to theory, but a sort of dynamic circle between different issues - some more dubious or problematic, others more likely to be taken for granted at a certain time. We could state that Dewey worked hard to bring into focus those behaviours of ours that are largely taken for granted. But he also worked on the other side of the matter, the question of the fixation of a new habit of mind, in Peirce's words, and particularly of those habits which come into play when we are required to make a conscious deliberation above all in those cases when we move from a mere «customary», but primary, morality to a more «reflexive» but secondary morality.

In those cases, we are neither connecting the representational content of an independent rule to a new empirical situation by means of what Wittgenstein calls a Deutung, nor calculating the agreeable and disagreeable 
consequences of a certain action, according to the utilitarian model leading to the idea of homo oeconomicus. According to Dewey, we are rather experimenting a «dramatic rehearsal (in imagination) of various competing possible lines of actions» (Dewey, 1988a, p. 132), which will bring us to a certain choice. We are imagining tentative alternatives, variations of the different possible interactions between an individual's actions and reactions and the unique context in which he undergoes and performs actions - this idea does not seem far from Wittgenstein's thoughts about human agency and the contribution a philosophical or reflective attitude could make to human life.

To conclude, does this mean that there is no more space for normativity if we understand rules in terms of human habits?

This is a huge issue, which I can only begin to approach in this paper. However, very briefly, I would summarize a Deweyan answer by saying that it largely depends on the way in which we understand what normativity is.

If it means the possibility or need to grasp a transcendental level of universal norms and principles, which should be valuable or true everywhere and at all times, independently of their empirical applications, evidently we must deny that for Dewey there is still place for this kind of claim. Moreover, we should ask the supporters of this perhaps old-fashioned yet still enduring idea of normativity how they envisage this realm.

But the pragmatist's answer can be a positive one if we understand norms as helpful tools for directing our conduct, as the highly significant outgrowth of previously reflexively considered habits, which at a certain moment and in a particular context required a deep revision, because of the changed conditions of action, and underwent a shared process of inquiry. Intelligent habits, reflexive morality and principles of conduct are considered the fruit of «past experimentation» and «cumulative evaluation» (Dewey, 1988a, p. 165) and can be an extremely fruitful means to face similar situations, as criteria for directing our actions. But contexts are everchanging and exchanges among humans are always unique, so that humans have to respond to objectively modified conditions, evaluating them by means of revised criteria, if the old ones no longer seem fit the new context. The evaluative moment is maintained and even reinforced by the lack of a general concept to which we could otherwise relatively easily ascribe the particular case. ${ }^{13}$ But from the pragmatist point of view, tertiur datur ${ }^{14}$ be-

${ }^{13}$ If we could adopt a model of judgement, it would have to be that of reflexive judgement and not that of determinant judgement, as described by Kant - even thought for Kant himself, of course, both in the epistemological domain and in the moral one we have a priori rules and consequently can effectively draw determinant connections between general concepts and empirical cases. 
yond the opposition between fixed, transcendental norms on the one hand and the total absence of norms on the other:

Yet the choice is not between throwing away rules previously developed and sticking obstinately by them. The intelligent alternative is to revise, adapt, expand and alter them. The problem is one of continuous, vital re-adaptation (Dewey, 1988a, p. 165).

\section{References}

Andronico M. (1998). Antropologia e metodo morfologico: studio su Wittgenstein. Napoli: La città del sole.

Bernstein R. (2010). The pragmatic turn. Cambridge: Polity Press.

Borutti S. (1985). Wittgenstein e l'orizzonte antropologico della regola. Nuova Civiltà Delle Macchine, 3, 3/4: 9-15, doi: 10.1007/s40329-014-0037-1

Bourdieu P. (1972). Esquisse d'une théorie de la pratique précédé de Trois études d'ethnologie kabyle. Paris: Seuil.

Bourdieu P. (1980). Le sens pratique. Paris: Les Editions de Minuit.

Brandom R. (1994). Making it explicit. Reasoning, representing, and discursive commitment. Cambridge: Harvard University Press.

Calcaterra R.M. (2016). Constructing on contingency: William James from biology to ethics and politics. Cognitio, 13,1:219-231.

Colapietro V. (2004). Doing - and undoing - the done thing: Dewey and Bourdieu on habituation, agency, and transformation. Contemporary Pragmatism, 1, 2: 65-93, doi: 10.1163/18758185-90000141.

Cometti J.-P. (2008). Qu'est-ce qu'une règle. Éducation et Didactique, 2, 2: 141150, doi: 10.4000/educationdidactique.329.

Dewey J. (1976). Interpretation of savage mind. In: The middle works, 1899-1924, Volume 2: 1902-1903, Carbondale \& Edwardsville: Southern Illinois University Press: $39-52$.

Dewey J. (1988a). Human nature and conduct. The middle works, 1899-1924, Volume 14: 1922, Carbondale \& Edwardsville: Southern Illinois University Press.

Dewey J. (1988b). The vanishing subject in the psychology of James. In: The later works, 1925-1953, Volume 14: 1939-1941, Carbondale \& Edwardsville: Southern Illinois University Press: 155-167.

Dewey J. (1989). Art as experience. The later works, 1925-1953, Volume 10: 1934, Carbondale \& Edwardsville: Southern Illinois University Press.

Diamond C. (1983). Wittgenstein on rules and private language. Philosophical Books, 24, 2: 96-98, doi: 10.1111/j.1468-0149.1983.tb00194.x.

Dreon R (2010). John Dewey: l'abito fa il naturalismo culturale. Bollettino Filosofico, XXVI: 169-182.

${ }^{14}$ On the possibility to depart from an «all encompassing bivalence», see Margolis (1999, p. 45). 
James W. (1981). The principles of psychology. 2 vols., Cambridge: Harvard University Press.

Kestenbaum V. (1992). Meaning on the model of truth. Dewey and Gadamer on habit and Vorurteil. The Journal of Speculative Psychology. New Series, 6, 1: 25-66.

Kripke A.S. (1982). On rules and private language. Oxford: Blackwell.

Leary D.E. (2013). A moralist in an age of scientific analysis and skepticism: habit in the life and work of William James. In: Sparrow T. and Hutchinson A., eds. A history of habit. From Aristotle to Bourdieu. Plymouth: Lexington Books: 177-208.

MacMullan T. (2013). The fly wheel of society. habit and social meliorism in the pragmatist tradition. In: Sparrow T. and Hutchinson A., eds. A history of habit. From Aristotle to Bourdieu. Plymouth: Lexington Books: 229-253.

Margolis J. (1999). Relativism and cultural relativity. In: What, after all, is a work of art? Lectures in the philosophy of art. University Park, PA: The Pennsilvania State University Press: 41-66.

Margolis J. (2002). Reinventing pragmatism. American philosophy at the end of the twentieth century. Ithaca: Cornell University Press.

McDowell J. (1984). Wittgenstein on following a rule. Synthèse, 58, 3, Essays on Wittgenstein's later philosophy: 325-363.

Mead G.H. (2011a), Social psychology as counterpart to physiological psychology. In: Deegan M.J., ed. Essays in social psychology. New Brunswick-London: Transaction Publishers: 9-17.

Mead G.H. (2011b), The relation of the embryological development to education. In: Deegan M.J., ed. Essays in social psychology. New Brunswick-London: Transaction Publishers: 73-82.

Mithen S., Parsons L. (2008). The brain as cultural artifact. Cambridge Archeological Journal, 18, 3: 415-422, doi: 10.1017/s0959774308000450.

Perissinotto L. (1997). Wittgenstein. Una guida. Milano: Feltrinelli.

Rofena C. (2011). Wittgenstein e l'errore di Frazer. Etica morfologica ed estetica antropologica. Milano-Udine: Mimesis.

Shusterman R. (2008). Redeeming somatic reflection: John Dewey's somatic philosophy of body-mind. In: Body consciousness. A philosophy of mindfuless and somaesthetics. Cambridge: Cambridge University Press: 180-216.

Sullivan S. (2013). Oppression in the gut. The biological dimensions of Deweyan habit. In: Sparrow T. and Hutchinson A., eds. A history of habit. From Aristotle to Bourdieu. Plymouth: Lexington Books: 255-271.

Winch P. (1990; 2nd ed.). The idea of a social science and its relation to philosophy. London: Routledge.

Wittgenstein L. (1953). Philosophical investigations, ed. by G.E.M. Anscombe and R. Rhees, Oxford: Blackwell. 